Discussion Paper No. 09-024

Good Occupation - Bad Occupation?

The Quality of Apprenticeship Training

Kathrin Goeggel and Thomas Zwick

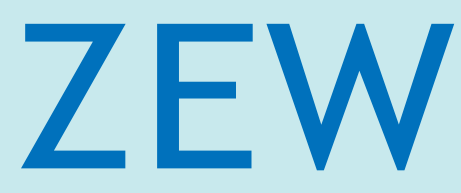

Zentrum für Europäische Wirtschaftsforschung $\mathrm{GmbH}$

Centre for European

Economic Research 
Discussion Paper No. 09-024

\section{Good Occupation - Bad Occupation? The Quality of Apprenticeship Training}

Kathrin Goeggel and Thomas Zwick

Download this ZEW Discussion Paper from our ftp server:

ftp://ftp.zew.de/pub/zew-docs/dp/dp09024.pdf

Die Discussion Papers dienen einer möglichst schnellen Verbreitung von neueren Forschungsarbeiten des ZEW. Die Beiträge liegen in alleiniger Verantwortung der Autoren und stellen nicht notwendigerweise die Meinung des ZEW dar.

Discussion Papers are intended to make results of ZEW research promptly available to other economists in order to encourage discussion and suggestions for revisions. The authors are solely responsible for the contents which do not necessarily represent the opinion of the ZEW. 


\section{Nontechnical summary}

This paper measures the quality of apprenticeship training by comparing the wage difference between apprentices who change their employer or occupation directly after the training period with apprentices who stay in the training firm and their occupation. It tests empirically which individual, occupation, and employer characteristics have an impact on these differences. A little wage advantage for those who change their employer after the apprenticeship training is an indication that the German dual apprenticeship training system provides generally usable human capital. There are small average wage losses for occupation changers who do not simultaneously change their employer. In general, a change of occupation does not have a wage impact. These average effects mask large differences by occupation groups, however. For apprentices in commerce and trading occupations, changing the employer is associated with a large positive wage mark-up. Apprentices in industrial occupations suffer from wage disadvantages when they have to change their employer or occupation. These results support the findings that industrial occupations are relatively specific and establishments that offer industrial occupations invest in apprenticeship training, try to keep their apprentices after the training period and offer attractive internal labour markets. Apprentices with an upper secondary education who change their employer get a higher wage mark-up than the stayers - this indicates that better qualified apprentices are privileged because they have the interesting outside option to acquire an academic qualification. The distinction between occupation groups and apprentices with different schooling back-grounds is new. The previous literature mainly concentrates on differences in economic sectors and firm size. We do not find large wage differences for occupation and/or employer changers in East-Germany, between the manufacturing and services sectors or from an apprenticeship training establishment which is smaller than the first skilled employer, however.

A series of robustness checks demonstrates that occupation selection, the decision to change the employer and/or occupation, unobserved heterogeneity between apprentices, and the homogeneity of the sample regarded all have a strong impact on the estimation results. This indicates that previous results might be biased. 


\section{Nichttechnische Zusammenfassung}

Dieser Beitrag misst die Qualität der Lehrlingsausbildung durch Lohnvergleiche von Lehrlingen, die entweder ihren Arbeitgeber oder ihren Beruf direkt nach Beendigung der Ausbildung wechseln mit denjenigen, die im Betrieb und Beruf verbleiben. Ein geringer Lohnvorteil von Berufswechslern ist ein Indikator dafür, dass das deutsche duale Ausbildungssystem im Durchschnitt allgemein auf dem Arbeitsmarkt brauchbare Qualifikationen vermittelt. Berufswechsler, die nicht gleichzeitig ihren Arbeitgeber nach der Ausbildungszeit wechseln haben einen kleinen Lohnnachteil. Diese durchschnittlichen Effekte verdecken jedoch große Differenzen zwischen Berufsgruppen. Für Auszubildende in Handelsberufen ist ein Arbeitgeberwechsel mit einem starken Lohnaufschlag verbunden. Auszubildende in industriellen Berufen hingegen sehen sich starken Lohnnachteilen gegenüber, wenn sie ihren Arbeitgeber oder den Beruf wechseln. Diese Resultate unterstützen die Erkenntnis, dass industrielle Berufe relativ unternehmensspezifisch sind und dass Unternehmen, die diese Berufe anbieten, in die Ausbildung investieren, die Absolventen $\mathrm{zu}$ halten versuchen und attraktive interne Arbeitsmärkte für die Auszubildenden anbieten. Auszubildende mit Abitur erhalten einen Lohnvorteil, wenn sie den Arbeitgeber wechseln - dies könnte ein Hinweis darauf sein, dass diese Personengruppe aufgrund ihrer Außenoption ein Studium aufzunehmen privilegiert ist. Die Unterscheidung zwischen Berufsgruppen und Auszubildenden mit unterschiedlicher Schulvorbildung wir in diesem Beitrag zum ersten Mal getroffen. In der bisherigen Literatur werden vor allem Unterschiede zwischen Wirtschaftssektoren und Unternehmensgrößen untersucht. Wir finden jedoch kaum Lohnunterschiede für Wechsler in Ostdeutschland, zwischen verarbeitendem und Dienstleistungssektor und von einem kleineren zu einem größeren Betrieb.

Eine Reihe von Robustheitstests zeigt, dass Selektivität von Berufswahl, Arbeitgeber oder Berufswechsel, unbeobachtete Heterogenität zwischen Auszubildenden und die Homogenität der betrachteten Ausbildenden einen starken Einfluss auf die Ergebnisse haben können. 


\title{
Good Occupation - Bad Occupation? The Quality of Apprenticeship Training
}

\author{
Kathrin Goeggel, Federal Ministry of Labour and Social Affairs (BMAS), Berlin \\ Thomas Zwick, Ludwig-Maximilians University, Munich \\ and Centre for European Economic Research, Mannheim*
}

May 2009

\begin{abstract}
Small average wage effects of employer and/or occupation changes mask large differences between occupation groups and apprentices with different schooling back-grounds. Apprentices in commerce and trading occupations strongly profit from an employer change. Employer and occupation changers in industrial occupations face large wage disadvantages however. We are the first to analyse these differences. Quality differences of apprenticeship quality between training firms that have been mainly discussed so far are small, however. This paper also explains differences between previous findings by comparing their estimation strategies. It demonstrates that selectivity into occupations and changers, unobserved heterogeneity between occupations, and the sample selection matter and proposes several improvements in the estimation technique to measure apprenticeship quality.
\end{abstract}

JEL Codes: J24; J31; M53

Key-Words: Wage mark-up, apprenticeship training, occupations

\footnotetext{
* Corresponding author, E-mail: zwick@bwl.Imu.de, address: LMU, Munich School of Management, Ludwigstr. 28/RG, D-80539 Munich. We want to thank Uschi Backes-Gellner, Jens Mohrenweiser, Guido Schwerdt, Jens Suedekum, and Stefan Wolter for useful comments on this paper. We use data provided by the Forschungsdatenzentrum der BA am IAB (FDZ), Nuremberg. The data basis of this publication is the Employment Sample of the IAB (years 1993-2003). Data access was provided via guest research spells at FDZ and afterwards via controlled data remote access at the FDZ. This research has been partly financed by the German Science Foundation (DFG) (Research group "Heterogeneous Labor: Positive and Normative Aspects of the Skill Structure of Labor", project "Formation and Utilization of Differentiated Human Capital “, FR 715/4-4).
} 


\section{Introduction}

Differences in the quality of apprenticeship training are a recurring topic in the literature. Soskice (1994) argues that the German apprenticeship system can be split into two groups. According to this seminal paper the first group consists of high-quality apprenticeship programmes typically provided by large firms in industry and commerce. Apprentices in these economic sectors enjoy high take-over rates and low wage losses when they have to change their employer or occupation because the skills acquired during their apprenticeship are transferable and have a high value on the labour market. Most of those who pass through the second group of apprenticeships - low-quality and relatively cheap apprenticeships mainly provided by the crafts and construction sector - have a weaker qualification background. Therefore they rather accept low wages and employment as semiskilled employee in other establishments if they are not taken over because their alternative would be unemployment. Based on this paper, several contributions look at differences between earnings capacities of apprentices in different economic sectors in order to see whether Soskice's analysis can be supported empirically

The results of these studies are not conclusive, however. While some papers find clear differences between training establishments on the basis of wages of skilled employees with an apprenticeship degree, others conclude that all apprenticeship occupations offer comparable earnings opportunities. We argue that the differences in the findings can be explained by differences in the empirical approaches. More specifically, most papers only look at the impact of employer characteristics on wages in skilled jobs after the end of the apprenticeship training. We demonstrate that besides employer characteristics also occupation and individual characteristics play an important role for the earnings potential an apprenticeship provides. In addition, we show that not all relevant quality characteristics of apprenticeships have been studied so far. The average wage effect of changing the employer or the occupation masks large differences between the effects for different groups of occupations, training establishments, and apprentices with different schooling background. Finally, we demonstrate that taking into account differences in wages during the apprenticeship period, unobserved heterogeneity between changers and stayers, and the endogeneity of the decision to change the employer or the occupation lead to sizeable changes in the measured wage effects. 
The remainder of this paper is organised as follows: Section 2 gives a brief survey of the literature and some theoretical considerations on the relation between wages of stayers and changers after apprenticeship training and the quality of apprenticeship training. We describe our estimation strategy in Section 3, the data and some descriptive statistics in Section 4. Results are discussed in Section 5. Section 6 concludes.

\section{Background}

Most papers that investigate differences in the quality of apprenticeship training look at wage differences between stayers and changers of employers or occupations. The idea behind this procedure is that a change of the employer or the occupation reveals the transferability of skills acquired during the apprenticeship on the labour market. Many apprentices cannot be sure that they can stay in the establishment that provided their apprenticeship training or their occupation. The average retention rate after apprenticeship training in Germany is relatively stable around 65 percent (Franz and Zimmermann, 2002; Mohrenweiser and Backes-Gellner, 2008; Seibert and Kleinert, 2009). About 30 percent of the apprentices change their occupation within one year after the end of their apprenticeship training (Clark and Fahr, 2001). Only seven percent of occupation changers do not change their employer and 25 percent find a new employer within one month (Seibert and Kleinert, 2009). Therefore it is of key interest for the attractiveness of occupations whether there is a wage penalty of changing the employer or the occupation after the apprenticeship. The wage penalty for changers in comparison to stayers in addition gives us an insight on the specificity and transferability of skills obtained during the apprenticeship training. The basic idea is that the contents and the specificity of the skills bundle acquired are mainly determined by the occupation-specific curriculum (Berufsverordnung) that applies to all training establishments and is therefore given for the apprentice. If the apprenticeship provides mainly general (bundles of) human capital, apprentices should not face wage disadvantages when they change their employer or their occupation directly after their training. If most of the training is firm-specific, other firms are not willing to pay the same skilled wage for job starters who changed from another employer or occupation as for employees who have been trained by themselves (Lazear, 2003). 
All papers in the literature so far either look at wage consequences of occupation changes or employer changes. As a consequence, most contributions also only either control for differences between characteristics of establishments or occupations. This is a problem because both, occupation and employer characteristics have an impact on wages and the variables might be correlated - more attractive employers offer more attractive occupations and attract more able apprenticeship applicants, for example (Soskice, 1994). It is therefore not clear whether the differences between different employers are not mainly the result of differences in the occupations these firms offer or the training participants.

The first line of the literature looks at the wage consequences of employer changes. Bougheas and Georgellis (2004) find that apprentices who change their employer experience a wage gain in small firms and a wage loss in large firms. The wage losses of those who move immediately after the apprenticeship training are much larger than those of movers some time after working in a skilled job. Harhoff and Kane (1997) also find a positive wage markup for employer changers immediately after the apprenticeship training. They distinguish between employers from the industry and craft sectors and do not find any differences for those who change their employers immediately after their training. Werwatz (2002) finds that wage losses of changers are larger for apprentices trained in industrial firms. Acemoglu and Pischke (1998) also compare the wages of former apprentices who stay in their training firms with those who change for different reasons (voluntary quit, lay-off and military draft). They hardly find any differences between stayers and the different groups of movers when they control for three groups of apprenticeship types and some individual characteristics. The papers mentioned so far do not include indicators for occupations. Partly they use wage data long after the entry into the skilled labour market which incurs the risk that unobservable labour market characteristics after the apprenticeship period have an objectionable impact on the results. ${ }^{1}$

The second line of research concentrates on the wage effects of occupation changes. Occupations are closely related to tasks and therefore the quality of jobs for former apprentices mainly is determined by occupations instead of the characteristics of the employer (Poletaev and Robinson, 2008). In order to understand differences in the quality of apprenticeship training, we therefore propose to control for the occupation in addition to

\footnotetext{
${ }^{1}$ Harhoff and Kane (1997) only use employees with at least five years of experience, Werwatz (2002) includes observations with on average fifteen years experience, and Acemoglu and Pischke (1998) observe employees who are on average between 14 and 20 years in the labour market.
} 
the employer information. The literature that concentrates on occupation faces the problem that there are for example fifteen different occupations in electronic occupations that might have very similar skill demands while other occupations do not have close substitutes. It therefore seems almost impossible to find an indicator for the closeness of occupations with different names (Clark and Fahr, 2001). We adopt the pragmatic solution to differentiate changes between the first and second digit level of the occupational code.

Clark and Fahr (2001) find that the wage penalty of voluntarily moving out of the apprenticeship occupation is almost zero. For displaced workers, it is around ten percent, however. Mainly those who move to a different occupation than the one-digit number face costs of changing. They conclude that training is transferable within a broad occupational group but not outside of this group. Fitzenberger and Spitz (2004) also look at the wage effects of changing the occupation after the apprenticeship training. They find that occupation changers even enjoy a wage mark-up. The mark-up is higher if the apprenticeship occupations are used instead of the practiced occupations. They interpret this finding as an indication that apprentices on average change if they were trained in low paying occupations. Both papers do not include employer characteristics.

Besides comparing the wage effects of changing an occupation by sector, some authors also distinguish between occupations with different training length. Schwerdt and Bender (2003) estimate the determinants of an employer change after training. They interpret the length of the apprenticeship training as an indicator for the amount of specific human capital acquired. Winkelmann (1996) who examines the labour market prospects of apprentices in comparison to other education groups uses the length of the training spell as an indicator for the "intensity" of training. ${ }^{2}$ An empirical problem of the training length as an indicator of apprenticeship quality is that in the data sets available occupations with longer or shorter training periods but similar names can not be distinguished. Examples are training occupations that take place in full time schools instead of in the dual apprenticeship system ${ }^{3}$. In addition there can be a series of reasons for differences in observed training times such as time reductions for those with good school qualifications or repeating spells for those with

\footnotetext{
${ }^{2}$ Note that Winkelmann (1996) uses firm size as proxy for the quality of training because his data base, the GSOEP, does not include information on the sector of the establishment nor the occupation learnt.

${ }^{3}$ An example is the dual occupation Industriekaufmann versus the full school time occupation kaufmännischer Assistent.
} 
bad grades in some exams. In this paper, we therefore do not differentiate between lengths of training spells but look at differences within instead of between occupations.

Obviously, employer and occupation changers are not a random sample of the apprentices or skilled employees and therefore endogeneity might bias the results of wage regressions (Ryan, 2001). The main source of endogeneity is the decision to choose a certain employer and occupation. While most contributions try to solve the endogeneity problem by using instrumental variables ${ }^{4}$, some distinguish between (an indicator for) voluntary and involuntary changes (Clark and Fahr, 2001; Bougheas and Georgellis, 2004). The latter argue that the closure of an enterprise or mass lay-offs can be taken as indicators for an involuntary employer change. As a consequence those who change their employer or occupation after their former employer went bankrupt or dismissed many people are not subject to endogeneity because they did not voluntary decide to change. ${ }^{5}$

Dustmann et al. (1997) apply an ordinary least squares model, a Heckman selection model and a fixed establishment effects model for differences between the wages in the first skilled jobs of employer changers and stayers. The authors take into account that a transition oriented perspective is necessary because experiences during apprenticeship training might affect wages in the first skilled job and wages during apprenticeship training, in other words both wages are state dependent (Ryan, 2001). Dustmann et al. (1997) differentiate between eight economic sectors and find large differences in the wage mark-up for changers even after controlling for occupations. In their selection model, they use a Heckman correction term for the self-selection into the group of changers or stayers. The instruments used are the population density in the area where the firm is located as a measure of mobility costs and information on the percentage of firms which closes down in the respective year on a two digit industry level as a measure for involuntary changers. The Heckman correction term is significant and in comparison to the OLS results, only one significant coefficient stays the same in the instrumental variables regression. They find that those who change their employer and have a skilled employment in the raw materials, construction, or services

\footnotetext{
${ }^{4}$ Typical instruments used are whether the employee was drafted to military service after apprenticeship or differences in the time period between joining the firm as an apprentice and the firm failure (Acemoglu and Pischke, 1998; Dustmann and Meghir, 2003; Fitzenberger and Spitz, 2004; Fersterer et al., 2007).

${ }^{5}$ The contributions use the disappearance of the establishment indicator as a sign for the closure of an enterprise. This might be problematic because an establishment indicator might also cease to exist because the establishment restructures itself or is bought by another establishment without stopping operations.
} 
sector face wage disadvantages. In an additional estimation, Dustmann et al. (1997) include establishment fixed effects for the sub-sample of establishments with more than one apprentice. In this specification, no coefficient is significant any more which might be a consequence of the small sample size.

Euwals and Winkelmann (2004) find a small wage mark-up for employer changers. This mark-up is mainly driven by those who move to a larger firm after their apprenticeship training. There is a wage reduction, however, if the employer providing the first skilled job is smaller than the training firm. Euwals and Winkelmann (2004) also indirectly control for employer selectivity by adding wages during the apprenticeship training and include 47 occupation dummies in their skilled wage estimation.

We learn from the literature review that we should include indicators for occupations and employer characteristics. We should be careful in taking wages a long time period after the end of the apprenticeship period and hereby run the risk that confounding effects during the skilled career bias the results. In addition, we should include apprenticeship wages or other indicators for selectivity into apprenticeship occupations. Indicators for good and bad apprenticeships could be firm size, economic sector or occupation group. Finally, the endogeneity of changing an occupation or employer and unobserved heterogeneity between apprentices and skilled employees should be taken into account. The contributions by Dustmann et al. (1997) and Euwals and Winkelmann (2004) come closest to our approach because they include establishment and occupational characteristics and they try to take into account the endogeneity of staying or changing after apprenticeship period. Both contributions use the same dataset as we do, but different observation periods. We will show later that this entails a decisive disadvantage. In addition, we add further distinctions between employer and employee groups and provide an integrative overview over all approaches and their empirical results. In the next section, we describe in detail how we aim to obtain a homogeneous sample, control for endogeneity and distinguish between the effects for different sub-groups in order to answer the question whether there are good or bad apprenticeship occupations.

\section{Estimation Strategy}

In this paper, we aim at reducing the impact of selectivity and unobservable differences between changers and stayers by taking a number of estimation measures that go beyond 
the available evidence. We use a similar estimation strategy as for example Dustmann et al. (1997) and Euwals and Winkelmann (2004) but change some decisive details. First, we concentrate on a very homogeneous sample - apprentices just before the end of their apprenticeship training and at the beginning of their first job. This means that all individuals have neither tenure nor experience (differences in tenure or experience frequently drive wage differences between changers and stayers, Poletaev and Robinson, 2008). We only take those employees with gaps between the apprenticeship and the first job of less than 30 days and we measure the first skilled wage directly at the beginning of the job. ${ }^{6}$ Almost by definition, apprentices who stay in the same firm after completing their apprenticeship period do not have a long gap between apprenticeship and first skilled employment. ${ }^{7}$ In addition, we compare the differences between changers and stayers for three wage indicators: the wage during apprenticeship, the first skilled wage and the wage mark-up between the last apprenticeship spell and the first skilled employment. By including the wage during the apprenticeship and the wage mark-up between apprenticeship and first skilled job, we are able to capture unobserved heterogeneity in productive ability as well as training quality and intensity between movers and stayers that manifest themselves during the apprenticeship training (Winkelmann, 1996; Euwals and Winkelmann, 2004; von Wachter and Bender, 2006). If mainly apprentices with negative unobservable characteristics or in establishments with negative characteristics change the employer afterwards, this should be already detectable in lower wages during the apprenticeship - therefore the wage mark-up is more informative than comparisons of the first skilled wage.

We only look at wage deviations from the occupation mean in order to get rid of wage level effects between occupations for example based on differences in the length or

\footnotetext{
${ }^{6}$ Dustmann et al. (1997) and Euwals and Winkelmann (2004) use the version of the IABS until 1995. This version does not include exact notifications when apprentices finished their apprenticeship period. Therefore the last apprenticeship spell entails wages for a certain time spell from the skilled job for more than 20 percent of the observations. The authors therefore have to use the wage information from the first year after finishing the apprenticeship training. Hereby they capture heterogeneity in tenure in the first skilled job. In addition, they include observations with long unemployment or out of labour force spells between apprenticeship and skilled job - for example those who served in the army or did their civil service before starting their first skilled job.

${ }^{7}$ The only exception might be military quitters who return to their training employer (Acemoglu and Pischke, 1998). We therefore exclude apprentices who first serve in the army or other community services directly after their apprenticeship before they return to the labour market because these employment gaps might lead to wage reductions.
} 
intensity of apprenticeship training in the specific occupation after controlling for establishment characteristics.

The estimation procedures described so far should allow us to avoid unobserved timeinvariant heterogeneity and selectivity into occupations. The decision of staying or moving to another employer or occupation still might be endogeneous, however (Dustmann et al., 1997). Besides the differences in the quality of apprenticeships also the economic situation in the enterprise offering the apprenticeship might be decisive. Former apprentices might be forced to change their employer for example because it is in economic hardships and reduces the share of apprentices taken over. According to the literature on displaced workers, we argue that the true effect of changing the employer can only be measured for those who have to change jobs involuntarily. It can usually not be measured, however, whether an employee changes the employer voluntarily or not. Therefore, mass lay-offs preceding the change in employer (or unemployment) are taken as an indicator for an involuntary change (Jacobson et al., 1993; Bender et al., 2002). We therefore use the fact that the enterprise had a reduction in employment by more than 30 percent as an instrument for the stay/change decision. ${ }^{8}$ This means that we have to assume that the mass lay-off assumption is innocuous in the wage mark-up equation. In addition, in our instrumental variable regression we obtain an average treatment effect of the treated, i.e. the wage mark-up for those apprentices who changed their employer because it encountered a strong decline in employment (and presumably did not take over its apprentices as a consequence) and would have stayed in their training establishment otherwise (compare Imbens and Angrist, 1994).

Finally, besides obtaining unbiased wage differences between movers and changers the main purpose of this paper is to differentiate between certain apprenticeship quality indicators. The indicators relating to the size and the sector of the training firm or the first skilled job employer have been frequently used in the empirical literature. In addition to that, we introduce the school qualification of the apprentice, training in East or West

\footnotetext{
${ }^{8}$ Dustmann et al. (1997) use the percentage of firms which close down in the respective year on a two digit industry level as an instrument in the selectivity term. This means however that the instrument is on a higher aggregation level than the instrumented variables and not as closely related to the observation as instruments that directly apply to the individual employee. Dustmann and Meghir (2005) use firm closure from an additional data file that gives the number of employees. Unfortunately, we do not have this information.
} 
Germany and three homogeneous occupation groups as quality indicators. We therefore differentiate between:

- wage effect of a change between employer (with and without occupation change),

- wage effect of a change between occupation (with and without employer change). We distinguish between all occupation changes and those who at least change to an occupation that has a different number on the first level of the occupation classification,

- wage effect of an employer or occupation change from a smaller establishment during training to a larger employer for the first skilled job,

- wage effect of a change from the manufacturing to the service sector,

- wage effects for changers with higher secondary education (Abitur),

- wage effects for changers trained in East Germany,

- wage effects for occupation and employer changers in three selected homogeneous occupation groups (commerce and trading occupations, industrial occupations, and crafts and construction occupations).

The occupation groups have been defined on the basis of these theoretical considerations (Mohrenweiser and Zwick, 2008) ${ }^{9}$ : Commerce and trading occupations provide the apprentices with relatively general human capital such as communication skills and information and communication technology skills that are widely used in the enterprises employing these occupations. In these occupations, most enterprises demand rather similar skills in the areas communication as well as in information and communication technologies. These technologies are widely used in all enterprises and also the mixture of the skills demanded seems to be rather similar. In industrial occupations such as electronics, IT, chemicals and metal-working, it takes some time until proficiency is achieved, most apprenticeships take three and a half years instead of three years and it seems probable that additional experience after the completion of the apprenticeship training is necessary to reach full productivity. This means that the specificity of the skills learnt might be high. An additional argument for the high specificity of these occupations is that they are frequently new or recently adopted to the rapid technological change in these fields. Lazear (2003) argues that new skills might be more specific than traditional skills. Finally, skilled employees

\footnotetext{
${ }^{9}$ We exclude other occupations from the analysis because these groups are very heterogeneous.
} 
in industrial occupations are hard to find. This implies that training firms have relatively high retention rates, invest in apprenticeship training and offer attractive internal labour markets (Büchel and Neubäumer, 2001; Dionisius et al., 2008). In our last occupation group (crafts and construction occupations) the skills learnt might be rather general, the skill mix demanded however might differ between enterprises. A typical example might be the change between a small bakery to an industrial bakery after the apprenticeship. The quality of these apprenticeships might be low because the employers only provide their apprentices with the basic skills necessary for their specific job in order to save investment costs, apprenticeships usually take three years and most applicants have a weaker qualification background than the other occupation groups (Soskice, 1994; Dionisius et al., 2008).

Our distinction between the occupation groups is supported by the argument that the more specific the skill requirements of an occupation compared to the labour market in general, the smaller is the probability that workers change occupations after completion of apprenticeship training (Geel et al., 2008). Apprentices in more specific occupations are stuck because a change of occupation would reduce the value of their specific skill combination. Our occupation groups indeed differ with respect to the share of employer and occupation changers (compare Table $A 5^{10}$ and Mohrenweiser and Zwick, 2008) - in the commerce and trading occupations and in the construction and craft occupations changing employer and/or occupation is more common than in industrial occupations.

On the basis of the previous literature, we have contradictory hypotheses on the average wage impact of employer and occupation changes. We might expect however that a change into an occupation group that is nearer according to the occupation classification has a smaller negative impact on wages than a change to a more distant occupation group, compare Clark and Fahr (2001). According to the empirical evidence and our theoretical considerations, we expect the following impact of the interactions between occupation and/or employer changes: An increase in the firm size after changing should be positive for the changer (Winkelmann, 1996; Acemoglu and Pischke, 1998). A change from manufacturing to services should be negative (Werwatz, 2002). Apprentices with a higher secondary schooling background should be privileged and enjoy a higher training quality (Soskice, 1994). It is well known that many of the apprentices with a higher secondary

\footnotetext{
${ }^{10}$ The shares of changers in our table are lower than those presented in the literature because we only look at changers directly between the end of the apprenticeship period and the first skilled job and in addition restrict our sample to those without long interruption spells between apprenticeship period and skilled job.
} 
education choose the apprenticeship qualifications in Germany as a risk avoidance strategy (Pilz, 2009). As a consequence, they obtain better apprenticeship training and get favourable treatment by enterprises interested in attracting them after the end of their apprenticeship period. Apprentices in East Germany should encounter a stronger wage reduction because they face a worse external labour market situation with higher unemployment rates for skilled employees than the West German colleagues. For apprentices in commerce and trading occupations, we expect a positive impact because they work in an environment that supports changes, acquire relatively general human capital and relatively low investment by the training firms (Mohrenweiser and Zwick, 2008). For apprentices in industrial occupations a change should incur a wage loss because employers see changers as a negative selection and the human capital acquired is rather specific. In addition, high net costs induce employers to keep their (best) apprentices. Changers in the crafts and construction occupation also should face wage reductions because the quality in training is low, training contents are frequently specific, and other employers are not willing to take them for the same wage because an apprenticeship in these occupations is regarded as low quality (Soskice, 1994).

The econometric specification is a log-linear Ordinary Least Squares (OLS) estimation and has the following form:

$$
Y_{i}=\alpha+\beta^{\prime} X_{i}+\gamma^{\prime} V_{i}+\varepsilon_{i}
$$

where $Y_{i}$ is the individual deviation from the occupation-specific average wage or wage mark-up (in logs), $X$ is a change of employer or occupation dummy or an interaction term of this dummy with our groups of individuals, employers or occupations summarised above. $V$ is a vector of individual and firm-specific control variables.

We perform a couple of robustness checks that also allow us to compare our results to those presented in the literature. Our first reference is a pooled OLS estimation that includes all observations between one and a half years before the end of the apprenticeship training until two years after the beginning of the first skilled job (as long as the job was not changed). In order to have comparable results to those contributions that only use observations in skilled jobs, we also reduce our sample for the pooled OLS estimation to the 
observations in the first skilled job. In a next step, in order to get rid of unobservable timeinvariant heterogeneity such as work motivation or ability, we take into account individual fixed effects (Yankow, 2006). ${ }^{11}$ We take individual wage observations half a year, a year and one and a half years before the end of the apprenticeship training and half a year, a year, one and a half years, and two years after the first skilled job starts. Together with the information on the wage at the end of the apprenticeship training and at the start of the first skilled job, we therefore have maximally nine wage observations per person and can include a fixed effect $\delta_{i}$ into our wage equation:

$Y_{i t}=\alpha+\beta^{\prime} X_{i t}+\gamma^{\prime} V_{i t}+\delta_{i}+\varepsilon_{i t}$

In order to additionally check the robustness of the wage effects measured directly at the beginning of the first skilled job, we run further regressions with the wage mark-ups at the end of the apprenticeship training and half a year and one year after starting the first skilled job.

Finally, we take into account the possible endogeneity of changing after the apprenticeship training. According to the literature, we define a mass lay-off as a reduction in employment in one establishment larger than 30 percent of the labour force within one year. ${ }^{12}$ We therefore assume that the chance that somebody involuntary changed the employer is much higher if a mass lay-off took place in the last year of the apprenticeship. We show that the mass lay-off indicator is a valid instrument: Mass lay-offs are not correlated with the average ability of apprentice cohorts but induced by unexpected changes in labour demand. On the other hand, mass lay-offs are highly correlated with an apprentice's propensity to change the employer or the occupation (Von Wachter and Bender, 2006).

\footnotetext{
${ }^{11}$ Von Wachter and Bender (2006) and Dustmann et al., (1997) present establishment fixed effects regressions. This is conceptually different because it only wipes out unobserved heterogeneity between establishments that affects all apprentices irrespective of their occupation. In addition, they only can use establishments with more than one apprentice which dramatically reduces their sample because a large share of the establishments only employs one apprentice.

${ }^{12}$ Von Wachter and Bender (2006) use deviations from the average retention rate of the training firm as an instrument for involuntary employer change. We cannot construct the retention rate in our data, however, because we only observe a sample of the employees in each firm.
} 


\section{Data}

We use longitudinal official register data collected by the Institute for Employment Research (IAB) from the years 1993 to 2003. Constructing a subsample of individuals moving from apprenticeship to first employment, we exploit the so-called employment and benefits history (IABS04) with spell information for each individual in the sample. For the wage markup version, we observe the termination of the apprenticeship training and the start of the first skilled job for every individual only once, creating a sample of repeated cross-sections. For the pooled OLS versions with all wage observations or with the skilled wage observations, we can use several spells per employee.

We focus on employed individuals aged 16 to 25, their last apprenticeship training and their first skilled employment spell. Additionally, we eliminate those employees with either a university degree or an occupational degree which cannot be obtained by a dual vocational training (mostly full-time school-based training), compare Clark and Fahr (2001). Our interest is the wage difference between apprentices who remain with their training firm and/or occupation ('stayer') and those changing to another employer and/or occupation ('changer'). Until the year 1992, firms did not have to report a change in the status of their employee from apprentice to full-time employee if they stayed with their training firm. This is the reason why we consider spell information only from the year 1993 on (compare Dustmann et al., 1997). We therefore know the precise end of the apprenticeship and the precise start of the first skilled job and the related wages. We take the daily wage of the last spell before the end of the apprenticeship training and the first daily wage when working in a skilled job taking into account wage inflation.

Estimations on basis of the IABS are usually subject to the problem that wages are censored at the social benefit contribution ceiling and that also experience and tenure are censored at certain dates (1970 for West German employees). We only consider job starters with relatively low wages and therefore these data problems do not affect our estimations (Dustmann et al., 1997). The information on the schooling level of employees in the employment statistics may be inconsistent because the information is not obligatory in the IABS (Fitzenberger et al., 2006). The interaction terms between changers and higher secondary education might therefore be interpreted with caution. Finally, we use a trimmed sample where observations below the 1 percent and above the 99 percent deviation quantile are dropped in order to exclude outliers. 
On the firm level, information on the size of the training firm (during apprenticeship) and the employing firm (during the first skilled job) as well as the economic sector of the employing and training firm are used as control variables (see Table A.1 for details on variables). On the individual level, age, sex, and nationality are used as controls.

Please note that we observe the employer on the establishment level. This means that a change from one establishment to another within a conglomerate of establishments cannot be identified (Euwals and Winkelmann, 2004). Still, specific skills acquired might be lost when changing within establishments of a conglomerate. Descriptive statistics of our variables can be found in Table A.2.

\section{Results}

Our estimation results are displayed in Table 1. The first two columns explain the wage deviations from the occupational mean in the last spell of the apprenticeship, the second two columns the wage deviations in the first spell of the first skilled job, and the last two columns the deviation of the wage mark-up between last apprenticeship wage and first skilled wage. Our main interest lies in the coefficients of the employer changers (the first line). We find a significant negative wage impact of an employer change of about two percent on the first skilled wage (see column "first skilled job" in Table 1). This finding is analogous to the results presented by Bougheas and Georgellis (2004) and Dustmann et al. (1997) who use differences in the absolute average entry wage for all occupations. Contrary to that, Euwals and Winkelmann (2004) - who control for differences in apprenticeship wages - find a positive wage premium for employer changers. We show that the reason for these differences is that the employer changers had an even stronger negative wage disadvantage of more than three percent at the end of their apprenticeship period in comparison to the average occupation wage (compare column "apprenticeship" in Table 1). As a consequence, the true effect of employer changing is (weakly) significantly positive instead of significantly negative (see column "mark-up" in Table 1 ) $^{13}$. The negative wage coefficients reported in the literature for employer changers therefore seem to be a statistical artefact induced by not controlling for the lower wages of the changers already

\footnotetext{
${ }^{13}$ Please note that the coefficients between the columns do not add up because we use different sets of covariates controlling for establishment characteristics during apprenticeship training when the apprenticeship wage is explained and for establishment characteristics after the apprenticeship training when the first skilled wage is explained.
} 
during the apprenticeship training. We also find that those who were paid worse during their apprenticeship period (either because they have negative individual unobserved characteristics or their employers have negative unobserved characteristics) are stronger inclined to change the employer. This is particularly true for those skilled employees who change employer and occupation. The wage disadvantage of those who only change their employer after apprenticeship training without also changing their occupation is smaller and the wage mark-up does not significantly differ from that of the stayers (compare the first line in Table 2).

We now turn to the wage effects of changing the occupation classification at least at the second classification level. Those who change their occupation directly after their apprenticeship training without changing their employer suffer a small but significant wage mark-up disadvantage and those who change occupation and their employer do not face a wage disadvantage (lines two and three in Table 2). Occupation changers do have lower wages at the end of their apprenticeship training, however, also compare Fitzenberger and Spitz (2004). According to Clark and Fahr (2001) those who change to another occupation on the first classification level suffer a slightly larger wage disadvantage. As they have a lower wage already during their apprenticeship period, the wage mark-up is not significantly different from zero, however.

Particularly large are the wage advantages of changers with higher secondary education. This group has a share of roughly one percent and has to be treated especially favourably by prospective employers because it has the attractive outside option of obtaining an academic degree. In accordance with Euwals and Winkelmann (2004), we find that changers from a smaller to a larger enterprise profit from this decision. In the other subgroups, employer or occupation changers do not have different wage mark-ups in comparison to stayers (compare Table 2). Those who change from manufacturing to services have lower initial wages in their first skilled job (Werwatz, 2002). As their wages also have been lower already during their apprenticeship training, there is no difference in their wage mark-up. According to our hypothesis also East German occupation and employer changers suffer wage disadvantages - their mark-up is not significantly different from those who do not change, however.

If we group apprenticeships into relatively homogeneous occupation sub-groups, we find the following interesting pattern: in trading and commerce occupations, employer 
changers enjoy a significant positive wage mark-up. In industrial occupations the mark-up is significantly negative and for craft and construction occupations changers and stayers have the same wage mark-up. According to our hypotheses this might mean that the specificity of training contents in trading and commerce occupations is relatively low. As a consequence, establishments with apprentices in these occupations are not willing to invest (much) in apprenticeship training because their apprentices can leave their training firm without a cost (Mohrenweiser and Zwick, 2008). In industrial occupations employer changers suffer from a high specificity of their training and strong internal labour markets that reduce their employment opportunities outside of the training firm. Occupations changers in industrial occupations also face financial disadvantages whereas occupation changers in the other occupation groups do not have a disadvantage. The wage penalties of employer and occupation changers in industrial occupations induce training firms to invest in these apprenticeships (Mohrenweiser and Zwick, 2008).

In order to obtain comparable results to those derived in the previous literature, we also report the coefficients for employer and occupation change for the pooled OLS for the observations in the first skilled job. According to our previous results for differences in wages in the first skilled job, we get negative coefficients for employer and/or occupation changers (compare the first column in Table 3). The wage disadvantage is again higher for those who change at least the first level occupation classification than for the occupation changers who stay closer to their apprenticeship occupation. Please note that the coefficients obtained in the pooled OLS regressions are generally higher and more significant than in the regressions using the last apprenticeship wage, the first skilled wage or the wage mark-up. These results might be indications for an over-estimation of losses in previous papers that use wage information considerable time after the first skilled job started.

We eliminate unobserved time-invariant heterogeneity between employer and/or occupation stayers and changers by applying fixed effects regressions. Analogously to the wage mark-up results, the negative coefficients for occupation and employer changers disappear (also compare Dustmann et al., 1997). We find instead a small positive and significant impact for employer and occupation changers (except changes of occupation at least at the second occupation level, compare column 2 of Table 3). Also using observations some time before and after the start of the first skilled job again increases size and significance of the measured wage mark-up. 
The wage mark-up results in Tables 1 and 2 take into account financial disadvantages or advantages of changers during the apprenticeship training that are indicators of unobserved heterogeneity between both groups. Endogeneity of employer or occupation changing still remains a problem because we cannot assume that changing is random and selectivity can fully be captured by controlling the wage level during the apprenticeship training period. We therefore first explain in two Probit estimations the probability that an apprentice changes his or her occupation or employer including the covariates used in the wage equation plus a dummy variable indicating whether the number of employees decreased by more than 30 percent during the last half a year of the apprenticeship. The mass lay-off variable has high explanatory power (see Table A3 in the Appendix). Durbin-Wu-Hausman tests and Hausman tests indicate that employer and occupation changing are endogeneous in the wage mark-up estimation and our mass lay-off indicator is a valid instrument to control for endogeneity (also see Table A4). If we use the predicted change probability taking into account the mass lay-offs, the wage mark-up for employer changers increases to 0.34 and the mark-up for occupation changers decreases to -0.43 , both coefficients are not significant, however. This means that the coefficients increase (in absolute values) but lose significance. ${ }^{14}$

The analogous instrumental variables regressions for the pooled observations of skilled employment also lead to higher coefficients, the signs are unchanged, however (compare Table 4, columns three and four and Dustmann et al., 1997). As indicated previously, we strictly spoken cannot compare the coefficients in the IV and the OLS regressions because the IV coefficients apply for the specific group of apprentices who changed their employer or occupation because their establishment suffered a mass lay-off (average treatment effect of the treated).

In our last robustness check, we calculate the wage mark-up between the last apprenticeship wage and the wage 180 and 365 days after the start of the first skilled job for those who are still at the same employer after this period of time. The wage mark-up is stronger positive for employer changers than the wage mark-up directly measured at the start of the first skilled employment. For occupation changers without employer change the negative wage impact increases (in absolute values), compare Table A4. These results remain unchanged if we restrict both samples to those employees who are observed at the same

\footnotetext{
${ }^{14}$ Tentative regressions for the sub-groups including the predicted changing probabilities interacted with these groups (not shown here) indicate a similar trend for the coefficients of the IV mark-up regressions in comparison to the OLS regressions.
} 
employer half a year or a full year after starting their first skilled job. ${ }^{15}$ According to our dindings using the pooled skilled wages our results indicate that the wage effects measured some time after the actual start of the first skilled job are larger, it remains unclear whether it takes some time until the full wage effect of changing evolves or other unobservable events on the labour market or at the employers are the reason for these findings, however.

\section{Conclusions}

This paper tests several frequently discussed hypotheses on the quality of apprenticeship training in Germany. A distinction is made between apprenticeship training in companies of different size, in manufacturing vs. services, in East vs. West Germany, for apprentices with and without upper secondary school education and in three homogeneous occupation groups. The quality of apprenticeship training is measured by the wage loss incurred if an apprentice has to change his or her employer and/or the occupation directly after the training period. Besides using a homogeneous sample of apprentices directly before and after the end of the apprenticeship training, we simultaneously control for employer, individual, and occupation characteristics. In addition, we take into account the selection into the changer and stayer group, unobserved time invariant heterogeneity and differences in wages within instead of between occupations by using deviations from occupation means.

Little wage advantages for those who change their employers directly after the apprenticeship training are indicators for the German dual apprenticeship training system to provide generally usable human capital (Korpi and Mertens, 2003). There are small average wage losses of occupation changes for those who do not change their employer simultaneously. Occupation changes do not have a wage impact in general, however. These small average effects mask large differences by occupation groups. For apprentices in trading and commerce occupations changing employers is associated with a positive wage mark-up. Apprentices in manufacturing occupations (more specifically in metal working, electronics, IT, and chemicals occupations) suffer wage disadvantages when they have to change their employer and/or their occupation. Changers in crafts and construction occupations have the same wages as stayers. These findings do not necessarily mean that

\footnotetext{
${ }^{15}$ The coefficients and standard errors for the reduced sample for employer changers is for $180 / 365$ days respectively analogously to the wage mark-up calculated in Table 2: $0.004(0.003) / 0.003(0.003)$ and for occupation changers $-0.003(0.003) /-0.002(0.003)$.
} 
industrial occupations have a lower quality than trade and commerce occupations - we know indeed that they are characterised by longer training periods, better internal labour market prospects and higher (net) costs for the training firms. Wage disadvantages in industrial occupations therefore might mainly be the consequence of a higher specificity of training contents.

Those apprentices with an upper secondary education who change their employer enjoy wage advantages. This might be a consequence of their attractive outside options (an academic career instead of switching to another employer or occupation). We do not find differences for changers in East-Germany, between manufacturing and services or from a smaller apprenticeship establishment to a larger first skilled employer.

By comparing the results between the wage mark-up and wages in the last apprenticeship spell and the first skilled employment, we demonstrate that analyses that do not take into account differences in apprenticeship wages obtain biased results because changers frequently already earn lower wages during their apprenticeship period. In the literature this effect is controlled by using fixed effects regressions. Fixed effects regressions are problematic, however, because they use wage observations some time after the start of the first skilled job. We show that this leads to (potentially biased) higher and more significant findings. Taking into account selectivity into changing by using an instrumental variables approach entailing a mass lay-off variable for the last half a year of the apprenticeship period leads to an increase in the coefficients but a loss in their significance. Finally, we control for unobserved differences between occupations by using deviations from occupation means instead of between occupation comparisons.

This paper therefore demonstrates that differences in the estimation approach are an important reason for differences in findings on earnings capacities provided by different apprenticeship trainings. It additionally shows that differences in apprenticeship quality are usually small between economic sectors of the training firm or its size and location. These differences have been at the centre of interest in the previous literature, however. Large differences are found between occupation groups and the qualification background of apprentices - distinctions proposed in this paper for the first time.

So far, we only account for the establishment characteristics economic sector and firm size. It seems important, however, to compare the impact of other establishment characteristics such as industrial relations, profits or business strategy on apprenticeship 
quality that have not been analysed so far. We can assume that analogously to the large differences in occupation groups also certain training firms offer better earnings prospects for their apprentices after changing their employer and/or occupation. The exploitation of linked employer-employee data for this purpose is a promising field for further research on this topic.

\section{Literature}

Acemoglu, D. \& J.-S. Pischke (1998), 'Why do firms train? Theory and Evidence', Quarterly Journal of Economics 113 (1), 79-118.

Bender, S., Dustmann, C., Margolis, D. \& Meghir, C. (2002), Worker Displacement in France and Germany, in: Kuhn, P. (ed.), Losing Work, Moving on: International Perspectives on Worker Displacement, Kalamazoo: Upjohn Institute for Employment Research, 375-470.

Bougheas, S. \& Y. Georgellis (2004), 'Early Career Mobility and Earnings Profiles of German Apprentices: Theory and Empirical Evidence', LABOUR 18(2), 233-263.

Büchel, F. \& R. Neubäumer (2001), ‘Ausbildungsinadäquate Beschäftigung als Folge branchenspezifischer Ausbildungsstrategien'. Mitteilungen aus der Arbeitsmarkt- und Berufsforschung 34, 269-285.

Clark, D. \& R. Fahr (2001), The Promise of Workplace Training for Non-College-Bound Youth: Theory and Evidence from German Apprenticeship, IZA Discussion Paper 378, Bonn.

Dionisius, R., S. Muehlemann, H. Pfeifer, G. Walden, F. Wenzelmann \& S. Wolter (2008), Cost and Benefit of Apprenticeship Training: A Comparison of Germany and Switzerland, IZA Discussion Paper 3465, Bonn.

Dustmann, C., R. Euwals \& A. van Soest (1997), 'Wages in the First Job after Apprenticeship: Movers versus Stayers', Mitteilungen aus der Arbeitsmarkt- und Berufsforschung 30(3), 671-674.

Dustmann, C. \& C. Meghir (2005), 'Wages, Experience and Seniority', Review of Economic Studies 72, 77-108.

Euwals, R. \& R. Winkelmann (2004), 'Training Intensity and First Labor Market Outcomes of Apprenticeship Graduates', International Journal of Manpower 25(5), 447-463.

Fersterer, J., J.-S. Pischke, \& R. Winter-Ebmer (2007), 'Returns to Apprenticeship Training in Austria: Evidence from Failed Firms', Scandinavian Journal of Economics 110(4), 733-753. 
Fitzenberger, B. \& A. Spitz (2004), Die Anatomie des Berufswechsels: Eine empirische Bestandsaufnahme auf Basis der BIBB/IAB-Daten 1998/1999, in W. Franz, H. J. Ramser \& M. Stadler, eds, 'Bildung', Vol. 33 of Wirtschaftswissenschaftliches Seminar Ottobeuren, Mohr Siebeck, Tübingen, pp. 29-55.

Fitzenberger, B., A. Osikominu \& R. Völter (2006), 'Imputation Rules to Improve the Education Variable in the IAB Employment Subsample', Schmollers Jahrbuch 126 (3), 405436.

Franz, W. \& V. Zimmermann (2002), 'The Transition from Apprenticeship Training to Work', International Journal of Manpower 23 (5), 411-425.

Geel, R., J. Mure \& U. Backes-Gellner (2008), 'Specificity of Occupational Training and Occupational Mobility: An Empirical Study Based on Lazear's Skill-Weights Approach', Swiss Leading House Working Paper 38, Zurich.

Harhoff, D. \& T. Kane (1997), 'Is the German Apprenticeship System a Panacea for the U.S. Labor Market?', Journal of Population Economics 10(2), 171-196.

Imbens, G. \& J. Angrist (1994), 'Identification and Estimation of Local Average Treatment Effects', Econometrica 62, 467-475.

Jacobson, L., R. LaLonde \& D. Sullivan (1993), 'Earnings Losses of Displaced Workers', American Economic Review 83 (4), 685-708.

Korpi, T. \& A. Mertens (2003), 'Training Systems and Labor Mobility - A Comparison between Germany and Sweden' Scandinavian Journal of Economics 105 (4), 597-617.

Lazear, E. (2003), Firm-Specific Human Capital: A Skill-Weights Approach, NBER Discussion Paper 9679, Cambridge MA.

Mohrenweiser, J. \& U. Backes-Gellner (2008), Apprenticeship Training - What for? Investment in Human Capital or Substitute for Cheap Labour?, Swiss Leading House Working Paper 17, Zurich.

Mohrenweiser, J. \& T. Zwick (2008), Why do firms train apprentices? The net cost puzzle reconsidered, ZEW Discussion Paper 08-019, Mannheim.

Pilz, M. (2009), 'Why Abiturienten do an apprenticeship before going to university: the role of 'double qualifications in Germany', Oxford Review of Education 35 (2), 187-204.

Poletaev, M. \& C. Robinson (2008), 'Human Capital Specificity: Evidence from the Dictionary of Occupational Titles and Displaced Worker Surveys', Journal of Labor Economics 26 (3), 387-420. 
Ryan, P. (2001), 'The School-to-Work Transition: A Cross-National Perspective', Journal of Economic Literature 39 (1), 34-92.

Schwerdt, W. \& S. Bender (2003), 'Was tun Lehrlinge nach ihrer Ausbildung? Eine Analyse mit dem Linked Employer-Employee Datensatz des IAB', Mitteilungen aus der Arbeitsmarkt- und Berufsforschung 36 (1), 46-59.

Seibert, H. \& C. Kleinert (2009), 'Duale Berufsausbildung - Ungelöste Probleme trotz Entspannung', IAB Kurzbericht 10/2009, Nuremberg.

Soskice, D. (1994), Reconciling Markets and Institutions: The German Apprenticeship System, in: L. Lynch (ed.) Training and the Private Sector: International comparisons, University of Chicago Press, Chicago.

Von Wachter, T. \& S. Bender (2006), 'In the Right Place at the Wrong Time: The Role of Firms and Luck in Young Workers' Careers', American Economic Review 96(5), 1679-1705.

Werwatz, A. (2002), 'Occupational Mobility after Apprenticeship - How Effective is the German Apprenticeship System?', Applied Economics Quarterly 48(3-4), 279-303.

Winkelmann, R. (1996), 'Employment Prospects and Skill Acquisition of ApprenticeshipTrained Workers in Germany', Industrial and Labor Relations Review 49(4), 658-672.

Yankow, J. (2006), 'Why do cities pay more? An Empirical Examination of some Competing Theories of the Urban Wage Premium', Journal of Urban Economics 60, 139-161.

Zwick, T. (2007), 'Apprenticeship Training in Germany - Investment or Productivity Driven?', Zeitschrift für Arbeitsmarktforschung 40(2/3), 193-204. 


\section{Tables}

Table 1: OLS regression explaining individual deviation from occupation-specific average wage or average wage mark-up

\begin{tabular}{|c|c|c|c|c|c|}
\hline \multirow[b]{3}{*}{ Employer change } & Apprenticeship & \multicolumn{2}{|c|}{ First skilled job } & \multicolumn{2}{|c|}{ Mark-up } \\
\hline & Coeff. & Coeff. & S. D. & Coeff. & S. D. \\
\hline & $-0.034^{* * *}(0.003)$ & $-0.022^{* * *}$ & $(0.003)$ & $0.006^{*}$ & $(0.003)$ \\
\hline Age & $0.023^{* * *}(0.001)$ & $0.016^{* * *}$ & (0.001) & $-0.008^{* * *}$ & * $(0.001)$ \\
\hline Sex & $-0.028^{* * *}(0.004)$ & $-0.035^{* * *}$ & $(0.003)$ & -0.005 & $(0.004)$ \\
\hline Nationality & $0.039^{* * *}(0.006)$ & $0.043^{* * *}$ & $(0.004)$ & 0.003 & $(0.006)$ \\
\hline Firm size dummies apprenticeship & Yes & No & & Yes & \\
\hline $\begin{array}{l}\text { Firm size dummies skilled } \\
\text { employment }\end{array}$ & No & Yes & & Yes & \\
\hline Sector dummies apprenticeship & Yes & No & & Yes & \\
\hline Sector dummies skilled employment & No & Yes & & Yes & \\
\hline Year dummies & Yes & Yes & & Yes & \\
\hline Constant & $-0.025^{* * *}(0.005)$ & -0.000 & $(0.004)$ & 0.011 & $(0.014)$ \\
\hline $\mathrm{N}$ & 50,699 & 50,699 & & 50,699 & \\
\hline Adj. $R^{2}$ & 0.098 & 0.116 & & 0.019 & \\
\hline
\end{tabular}

Data Source: IABS scientific usefile, waves 1993-2003.

Notes: Standard deviations in brackets. Significance levels: ${ }^{*}: 10 \%,{ }^{* *}: 5 \%,{ }^{* * *}: 1 \%$. 
Table 2: OLS regressions explaining individual deviation from occupation-specific average wage or average wage mark-up

\begin{tabular}{|c|c|c|c|c|c|c|}
\hline & \multicolumn{2}{|c|}{ Apprenticeship } & \multicolumn{2}{|c|}{ First skilled job } & \multicolumn{2}{|c|}{ Mark-up } \\
\hline & Coeff. & S.D. & Coeff. & S. D. & Coeff. & S. D. \\
\hline $\begin{array}{l}\text { Employer change without } \\
\text { occupation change }\end{array}$ & $-0.013^{* * *}$ & $(0.004)$ & -0.003 & $(0.003)$ & 0.003 & $(0.004)$ \\
\hline Occupation change & $-0.018^{* *}$ & $(0.004)$ & $-0.020^{* * *}$ & $(0.003)$ & -0.001 & $(0.003)$ \\
\hline $\begin{array}{l}\text { Occupation change without } \\
\text { employer change }\end{array}$ & $-0.021^{* * *}$ & $(0.005)$ & $-0.025^{* * *}$ & $(0.004)$ & $-0.007^{*}$ & $(0.004)$ \\
\hline Occupation change -2 & $-0.030^{* * *}$ & $(0.004)$ & $-0.028^{* * *}$ & $(0.003)$ & 0.004 & $(0.004)$ \\
\hline $\begin{array}{l}\text { Employer change } X \\
\text { manufacturing into services }\end{array}$ & $-0.135^{* * *}$ & $(0.008)$ & $-0.088^{* * *}$ & $(0.008)$ & 0.007 & $(0.012)$ \\
\hline $\begin{array}{l}\text { Occupation change } X \\
\text { manufacturing into services }\end{array}$ & $-0.141^{* * *}$ & $(0.011)$ & $-0.062^{* * *}$ & $(0.009)$ & -0.001 & $(0.013)$ \\
\hline $\begin{array}{l}\text { Employer change } X \text { change into } \\
\text { larger enterprise }\end{array}$ & $-0.069^{* * *}$ & $(0.005)$ & $-0.091^{* * *}$ & $(0.005)$ & 0.008 & $(0.005)$ \\
\hline $\begin{array}{l}\text { Occupation change } X \text { change } \\
\text { into larger enterprise }\end{array}$ & $-0.081^{* * *}$ & $(0.008)$ & $0.022^{* * *}$ & $(0.005)$ & 0.054 & $(0.036)$ \\
\hline $\begin{array}{l}\text { Employer change } X \text { upper } \\
\text { secondary education }\end{array}$ & $0.022^{* *}$ & $(0.009)$ & $0.059^{* * *}$ & $(0.007)$ & $0.045^{* * *}$ & $(0.009)$ \\
\hline $\begin{array}{l}\text { Occupation change } \mathrm{X} \text { upper } \\
\text { secondary educ. }\end{array}$ & 0.018 & $(0.011)$ & $0.037^{* *}$ & (0.011) & 0.019 & $(0.012)$ \\
\hline $\begin{array}{l}\text { Employer change } X \text { East } \\
\text { Germany }\end{array}$ & $-0.227^{* * *}$ & $(0.007)$ & $-0.216^{* * *}$ & $(0.006)$ & 0.007 & $(0.008)$ \\
\hline $\begin{array}{l}\text { Occupation change X East } \\
\text { Germany }\end{array}$ & $-0.205^{* * *}$ & $(0.008)$ & $-0.208^{* * *}$ & $(0.007)$ & -0.004 & $(0.008)$ \\
\hline $\begin{array}{l}\text { Employer change } \mathrm{X} \text { commerce } \\
\text { and trading }\end{array}$ & $-0.029^{* * *}$ & $(0.004)$ & $0.016^{* * *}$ & $(0.004)$ & $0.032^{* * *}$ & $(0.005)$ \\
\hline $\begin{array}{l}\text { Employer change } X \text { industrial } \\
\text { occupations }\end{array}$ & $-0.030^{* * *}$ & $(0.006)$ & $-0.046^{* * *}$ & $(0.005)$ & $-0.024^{* * *}$ & $(0.006)$ \\
\hline $\begin{array}{l}\text { Employer change } \mathrm{X} \text { crafts and } \\
\text { construction }\end{array}$ & $-0.051^{* * *}$ & $(0.006)$ & $-0.038^{* * *}$ & $(0.005)$ & -0.005 & $(0.007)$ \\
\hline $\begin{array}{l}\text { Occupation change } \mathrm{X} \text { commerce } \\
\text { and trading }\end{array}$ & $-0.013^{* *}$ & $(0.006)$ & $-0.009^{*}$ & $(0.005)$ & 0.002 & $(0.006)$ \\
\hline $\begin{array}{l}\text { Occupation change } X \text { industrial } \\
\text { occupations }\end{array}$ & $-0.013^{* *}$ & $(0.005)$ & $-0.030^{* * *}$ & $(0.005)$ & $-0.018^{*}$ & $(0.006)$ \\
\hline $\begin{array}{l}\text { Occupation change } \mathrm{X} \text { crafts and } \\
\text { construction }\end{array}$ & $-0.054^{* * *}$ & $(0.008)$ & $-0.047^{* * *}$ & $(0.007)$ & 0.003 & $(0.008)$ \\
\hline
\end{tabular}

Notes: Covariates (besides employer change) and other notes as in regressions in Table 1, every line separate regression besides joint estimations using three occupation dummy interaction. 
Table 3: Pooled OLS and fixed effects regressions explaining individual deviation from occupation-specific wage

\begin{tabular}{lcccc}
\hline \hline & \multicolumn{2}{c}{ Pooled OLS } & \multicolumn{2}{c}{ Fixed Effects } \\
\hline & Coeff. & S.D. & Coeff. & S. D. \\
$\begin{array}{l}\text { Employer } \\
\text { Change }\end{array}$ & $-0.065^{* * *}$ & $(0.022)$ & $0.012^{* * *}$ & $(0.001)$ \\
$\begin{array}{l}\text { Employer } \\
\text { change without } \\
\text { occupation } \\
\text { change }\end{array}$ & $-0.025^{* * *}$ & $(0.002)$ & $0.013^{* * *}$ & $(0.001)$ \\
$\begin{array}{l}\text { Occupation } \\
\text { change }\end{array}$ & $-0.066^{* * *}$ & $(0.002)$ & $0.007^{* * *}$ & \\
$\begin{array}{l}\text { Occupation } \\
\text { change without } \\
\text { employer } \\
\text { change }\end{array}$ & $-0.014^{* * *}$ & $(0.004)$ & $0.007^{* * *}$ & $(0.002)$ \\
$\begin{array}{l}\text { Occupation } \\
\text { change - } 2\end{array}$ & $-0.075^{* * *}$ & $(0.003)$ & -0.006 & $(0.004)$ \\
\hline \hline
\end{tabular}

Data Source: IABS scientific usefile, waves 1993-2003.

Notes: Standard deviations in brackets. We take individual cluster effects into account in the pooled OLS regressions. Covariates in OLS regressions: age, sex, nationality, size and sector of first skilled employer, year dummies; covariates in FE regression are the same except sex and nationality. Significance levels: ${ }^{*}: 10 \%,{ }^{* *}: 5 \%,{ }^{* * *}: 1 \%$. 
Table 4: Instrumental variable regression explaining individual deviations from occupation-specific deviations for the first skilled wages and the wage mark-up between apprenticeship and first skilled wage

\begin{tabular}{|c|c|c|c|c|c|c|}
\hline & $\begin{array}{l}\text { IV Wage N } \\
\text { Employer }\end{array}$ & $\begin{array}{l}\text { Mark-up } \\
\text { Change }\end{array}$ & $\begin{array}{l}\text { IV Wage N } \\
\text { Occupation }\end{array}$ & $\begin{array}{l}\text { Mark-up } \\
\text { n Change }\end{array}$ & $\begin{array}{l}\text { Pooled IV First } \\
\text { Skilled Wage } \\
\text { Employer } \\
\text { Change }\end{array}$ & $\begin{array}{l}\text { Pooled IV First } \\
\text { Skilled Wage } \\
\text { Occupation } \\
\text { Change }\end{array}$ \\
\hline & Coeff. & $\begin{array}{l}\text { Std. } \\
\text { Dev. }\end{array}$ & Coeff. & Std. Dev. & Coeff. & Coeff. \\
\hline Change & 0.047 & $(0.030)$ & -0.034 & $(0.025)$ & $-0.156^{* * *}$ & -0.049 \\
\hline Age & $-0.006^{* * *}$ & $(0.001)$ & $-0.006^{* * *}$ & $(0.001)$ & $0.010^{* * *}$ & $0.009^{* * *}$ \\
\hline Sex & $-0.009 * *$ & $(0.004)$ & $-0.008 *$ & $(0.004)$ & $-0.017^{* *}$ & $-0.016^{* * *}$ \\
\hline Nationality & 0.005 & $(0.006)$ & $0.006^{* * *}$ & $(0.006)$ & $0.046^{* * *}$ & $0.043^{* * *}$ \\
\hline $\begin{array}{l}\text { Firm size } \\
\text { apprenticeship } \\
\text { dummies }\end{array}$ & Yes & & Yes & & No & No \\
\hline $\begin{array}{l}\text { Firm size skilled } \\
\text { employment } \\
\text { dummies }\end{array}$ & Yes & & Yes & & Yes & Yes \\
\hline Sector dummies & Yes & & Yes & & Yes & Yes \\
\hline Year dummies & Yes & & Yes & & Yes & Yes \\
\hline Constant & -0.006 & $(0.012)$ & -0.004 & $(0.013)$ & $-0.216^{* * *}$ & $-0.203^{* * *}$ \\
\hline Observations & 41892 & & 41892 & & 96572 & 96572 \\
\hline Adj. $R^{2}$ & 0.018 & & 0.018 & & 0.108 & 0.108 \\
\hline
\end{tabular}

Data Source: IABS scientific usefile, waves 1993-2003.

Notes: Standard deviations in brackets, significance levels: ${ }^{*}: 10 \%^{* *}{ }^{* *}: 5 \%,{ }^{* * *}: 1 \%$. 
Table A.1: Variable Definition

\begin{tabular}{|c|c|c|}
\hline Variable & Type $^{*}$ & Definition \\
\hline \multicolumn{3}{|l|}{ Dependent variables } \\
\hline Deviation first job & Dev. & $\begin{array}{l}\text { Positive if individual earns in its first job more than the } \\
\text { occupation/year specific average }\end{array}$ \\
\hline $\begin{array}{l}\text { Deviation } \\
\text { Apprenticeship }\end{array}$ & Dev. & $\begin{array}{l}\text { Positive if individual earns at the end of the apprenticeship period } \\
\text { more than the occupation/year specific average }\end{array}$ \\
\hline Deviation mark-up & Dev. & $\begin{array}{l}\text { Positive if individual has a higher wage mark-up than the } \\
\text { occupation/year specific average }\end{array}$ \\
\hline \multicolumn{3}{|l|}{ Variables of interest } \\
\hline Employer & $0 / 1$ & 1 if individual changed employer after apprenticeship \\
\hline ation & $0 / 1$ & $\begin{array}{l}1 \text { if individual changed occupation after apprenticeship at least at } \\
\text { the second occupational level }\end{array}$ \\
\hline Occupation & $0 / 1$ & $\begin{array}{l}1 \text { if individual changed occupation at least at the first } \\
\text { occupational level }\end{array}$ \\
\hline $\begin{array}{l}\text { Occupation } \\
\text { dummies }\end{array}$ & $1-3$ & $\begin{array}{l}\text { Commerce and trading occupations, industrial occupations and } \\
\text { crafts/construction occupations }\end{array}$ \\
\hline \multicolumn{3}{|c|}{ Explanatory variables } \\
\hline Age & Dev. & led employment \\
\hline Sex & Dev. & Positive if individu \\
\hline Nationality & Dev. & Positive if individual has foreign nationality \\
\hline $\begin{array}{l}\text { Higher Secondary } \\
\text { Education }\end{array}$ & Dev. & $\begin{array}{l}\text { Positive if individual has completed a higher secondary school } \\
\text { education (Abitur) }\end{array}$ \\
\hline Uner & Dev. & $\begin{array}{l}\text { Positive if individual was registered unemployed after } \\
\text { apprenticeship }\end{array}$ \\
\hline $\begin{array}{l}\text { Firm size } \\
\text { apprentice }\end{array}$ & Dev. & $\begin{array}{l}\text { Size of the training firm, } 8 \text { dummies for } 1-9,10-49,50-99,100-249 \text {, } \\
250-499,500-999,1000-4999,5000+\text { employees }\end{array}$ \\
\hline Firm size employee & Dev. & Size of firm in first skilled job, 8 dummies \\
\hline $\begin{array}{l}\text { Firm sector } \\
\text { dummies }\end{array}$ & $0 / 1$ & $\begin{array}{l}\text { Dummies for: Water and power, manufacturing, construction, } \\
\text { trading, traffic and communication, finance, hospitality and } \\
\text { restaurants, rent and lease, services }\end{array}$ \\
\hline Y1994 to Y2003 & $0 / 1$ & Year dummies for 1994 to 2003, reference year: 1993 \\
\hline
\end{tabular}

Notes: ${ }^{*} 0 / 1=$ dummy variable, dev. = variable computed as individual deviation from the mean by occupation and year. 
Table A.2: Summary statistics in absolute values dependent variables

\begin{tabular}{lllll}
\hline \hline & \multicolumn{3}{c}{ Variable } & \multicolumn{3}{c}{ Mean Std. Dev. Min MaX } \\
\hline Employer change & 0.190 & $(0.301)$ & 0 & 1 \\
Employer change without occupation change & 0.088 & $(0.283)$ & 0 & 1 \\
Occupation change & 0.160 & $(0.367)$ & 0 & 1 \\
Occupation change without employer change & 0.055 & $(0.228)$ & 0 & 1 \\
Occupation change -1 & 0.141 & $(0.348)$ & 0 & 1 \\
Commercial trading & 0.084 & $(0.277)$ & 0 & 1 \\
Employer change X change from manufacturing into services & 0.023 & $(0.149)$ & 0 & 1 \\
Occupation change X change manufacturing into services & 0.016 & $(0.130)$ & 0 & 1 \\
Employer change X change into larger enterprise & 0.089 & $(0.286)$ & 0 & 1 \\
Occupation change X change into larger enterprise & 0.098 & $(0.298)$ & 0 & 1 \\
Employer change X upper secondary education & 0.013 & $(0.113)$ & 0 & 1 \\
Occupation change X upper secondary education & 0.010 & $(0.098)$ & 0 & 1 \\
Employer change X East Germany & 0.087 & $(0.282)$ & 0 & 1 \\
Occupation change X East Germany & 0.071 & $(0.258)$ & 0 & 1 \\
Employer change X commercial trading occupations & 0.063 & $(0.243)$ & 0 & 1 \\
Employer change X metal working occupations & 0.018 & $(0.135)$ & 0 & 1 \\
Employer change X crafts and construction occupations & 0.031 & $(0.173)$ & 0 & 1 \\
Occupation change X commercial trading occupations & 0.046 & $(0.209)$ & 0 & 1 \\
Occupation change X industrial occupations & 0.020 & $(0.144)$ & 0 & 1 \\
Occupation change X crafts and construction occupations & 0.020 & $(0.141)$ & 0 & 1 \\
\hline \hline
\end{tabular}

Data Source: Sample drawn from IABS scientific usefile, waves 1993-2003. 
Table A.3: Summary statistics in absolute values covariates

\begin{tabular}{|c|c|c|c|c|}
\hline \multirow{2}{*}{$\begin{array}{l}\text { Variable } \\
\text { Trading and commerce }\end{array}$} & \multicolumn{4}{|c|}{ Mean Std. Dev. Min Max } \\
\hline & 0.364 & $(0.500)$ & 0 & 1 \\
\hline Industrial occupations & 0.255 & $(0.227)$ & 0 & 1 \\
\hline Crafts, construction & 0.209 & $(0.133)$ & 0 & 1 \\
\hline Age & 20.958 & $(1.703)$ & 16 & 25 \\
\hline Sex & 0.410 & $(0.492)$ & 0 & 1 \\
\hline Nationality & 0.068 & $(0.251)$ & 0 & 1 \\
\hline Higher secondary education & 0.041 & (0.199) & 0 & 1 \\
\hline Unemployment & 0.002 & $(0.042)$ & 0 & 1 \\
\hline East Germany & 0.159 & $(0.365)$ & 0 & 1 \\
\hline Firm size app. ${ }^{*}<10$ & 0.177 & $(0.382)$ & 0 & 1 \\
\hline Firm size app. 10 - 49 & 0.285 & $(0.452)$ & 0 & 1 \\
\hline Firm size app. 50 - 99 & 0.112 & $(0.315)$ & 0 & 1 \\
\hline Firm size app. 100 - 249 & 0.142 & $(0.349)$ & 0 & 1 \\
\hline Firm size app. 250 - 499 & 0.097 & $(0.296)$ & 0 & 1 \\
\hline Firm size app. 500 - 999 & 0.078 & $(0.269)$ & 0 & 1 \\
\hline Firm size app. 1000 - 4999 & 0.084 & $(0.277)$ & 0 & 1 \\
\hline Firm size app. > 5000 & 0.024 & $(0.154)$ & 0 & 1 \\
\hline Firm size emp. ${ }^{* *}<10$ & 0.185 & $(0.388)$ & 0 & 1 \\
\hline Firm size emp. 10 - 49 & 0.293 & $(0.455)$ & 0 & 1 \\
\hline Firm size emp. 50 - 99 & 0.112 & $(0.315)$ & 0 & 1 \\
\hline Firm size emp. 100 - 249 & 0.138 & $(0.345)$ & 0 & 1 \\
\hline Firm size emp. 250 - 499 & 0.093 & $(0.290)$ & 0 & 1 \\
\hline Firm size emp. 500 - 999 & 0.073 & $(0.260)$ & 0 & 1 \\
\hline Firm size emp. 1000 - 4999 & 0.081 & $(0.273)$ & 0 & 1 \\
\hline Firm size emp. > 5000 & 0.024 & $(0.154)$ & 0 & 1 \\
\hline Water and power & 0.015 & $(0.121)$ & 0 & 1 \\
\hline Manufacturing & 0.359 & $(0.480)$ & 0 & 1 \\
\hline Construction & 0.131 & $(0.337)$ & 0 & 1 \\
\hline Trading & 0.206 & $(0.404)$ & 0 & 1 \\
\hline Traffic and communication & 0.038 & $(0.192)$ & 0 & 1 \\
\hline Finance & 0.119 & $(0.323)$ & 0 & 1 \\
\hline Hotels and restaurants & 0.013 & $(0.111)$ & 0 & 1 \\
\hline Rent and lease & 0.082 & $(0.275)$ & 0 & 1 \\
\hline Services & 0.038 & $(0.192)$ & 0 & 1 \\
\hline Number of observations & 30,642 & & & \\
\hline
\end{tabular}

Data Source: see Table A2, notes: * app. means employer during last spell of apprenticeship, ${ }^{* *}$ emp. means employer during first skilled job. 
Table A.3: Probit regressions explaining individual probability to change the employer or the occupation at the end of the apprenticeship period

\begin{tabular}{|c|c|c|c|c|}
\hline \multirow{2}{*}{$\begin{array}{l}\text { Variable } \\
\text { Mass lay-off in last half a year of } \\
\text { apprenticeship period }\end{array}$} & \multicolumn{2}{|l|}{ Employer change } & \multicolumn{2}{|c|}{ Occupation change } \\
\hline & $0.593 * * *$ & & $0.157 * * *$ & \\
\hline Age & $0.014 * * *$ & & $0.022 * * *$ & \\
\hline Sex & $0.165 * * *$ & & -0.008 & \\
\hline Nationality & -0.022 & & 0.003 & \\
\hline $\begin{array}{l}\text { Firm size dummies } \\
\text { apprenticeship }\end{array}$ & Yes & & Yes & \\
\hline $\begin{array}{l}\text { Firm size dummies skilled } \\
\text { employment }\end{array}$ & Yes & & Yes & \\
\hline Sector dummies apprenticeship & Yes & & Yes & \\
\hline $\begin{array}{l}\text { Sector dummies skilled } \\
\text { employment }\end{array}$ & Yes & & Yes & \\
\hline Year dummies & Yes & & Yes & \\
\hline Constant & $-1.684 * * *$ & & $-2.187 * * *$ & \\
\hline Pseudo $\mathrm{R}^{2}$ & 0.08 & & 0.08 & \\
\hline $\mathrm{N}$ & 41892 & & 41892 & \\
\hline $\begin{array}{l}\text { Durbin-Wu-Hausman chi-square } \\
\text { test }^{1}\end{array}$ & $\mathrm{~F}(1,41891)=3.940 * *$ & $(0.047)$ & $F(141891)=3.684^{*}$ & $(0.055)$ \\
\hline Wu-Hausman F test ${ }^{1}$ & Chi-sq(1) $=3.945^{* *}$ & $(0.047)$ & Chi-sq(1) =3.688* & $(0.055)$ \\
\hline
\end{tabular}

Data Source: IABS scientific usefile 1993-2003.

Notes: ${ }^{1} p$-values in brackets, significance levels: ${ }^{*}: 10 \%,{ }^{* *}: 5 \%,{ }^{* * *}: 1 \%$.

Table A.4: Regression with individual deviation from occupation-specific average wage markup between last apprenticeship wage and wage 180 and 365 days after entry into first job

\begin{tabular}{|c|c|c|c|c|}
\hline Variable & 180 days af & er entry & 365 after days er & \\
\hline Employer change & $0.023 * * *$ & $(0.004)$ & $0.035 * * *$ & $(0.004)$ \\
\hline Employer change without & & & & \\
\hline occupation change & $0.015^{* * *}$ & $(0.004)$ & $0.025 * * *$ & $(0.005)$ \\
\hline Occupation change & 0.000 & $(0.004)$ & 0.003 & $(0.004)$ \\
\hline $\begin{array}{l}\text { Occupation change without } \\
\text { employer change }\end{array}$ & $-0.017^{* * *}$ & $(0.005)$ & $-0.021 * * *$ & $(0.006)$ \\
\hline $\begin{array}{l}\text { Occupation change (1-digit } \\
\text { level occupation) }\end{array}$ & 0.004 & $(0.004)$ & 0.007 & $(0.005)$ \\
\hline
\end{tabular}

Data Source: IABS scientific usefile 1993-2003.

Notes: Significance levels: ${ }^{*}: 10 \%,{ }^{* *}: 5 \%,{ }^{* * *}: 1 \%$. 
Table A.5: Share of changers by occupation groups, directly after apprenticeship training

\begin{tabular}{lcc}
\hline Occupation group & $\begin{array}{c}\text { Share of employer } \\
\text { movers }\end{array}$ & $\begin{array}{c}\text { Share of occupation } \\
\text { movers }\end{array}$ \\
\hline Trading & 17.3 & 12.6 \\
Industrial & 10.9 & 7.8 \\
Crafts, construction & 14.7 & 9.6 \\
Average (including other occupations) & 15.9 & 13.1 \\
\hline
\end{tabular}

Data Source: IABS scientific usefile 1993-2003, complete sample. 